\section{Treatment of Malignant Growths}

Dr. Russerd. H. Boags, Pittsburgh, Pa.: The degree of malignancy varies with the lymph supply of that part of the body in which a cancer is situated. The richer the lymph supply, the greater the degree of malignancy. When properly applied, Roentgen irradiation diminishes the permeability of the lymph vessels, and reduces the possiljility of metastasis occurring as well as preventing, in large mensure, a recurrence. If the treatment is given before operation, an inoperable case may be converted into an operable one. Every malignant growth presents a separate and distinct problem which demands for its solution consistent tenm work on the part of the patient and the operator. The improvements in surgical technic have done much to reduce the number of recurrences of cancer, but expert surgeons are not satisfied with the results obtained from surgery.

Roentgen irradiation of malignant growths must be powerful enough to destroy the neoplastic cells and to stimulate the healthy cells to resist the invasion. A small dose is: useless. Small doses griven for a long time really favor the development of the growth, because. they stimulate, wherens they should destroy. I have treated quite a number of cases of lymphosarcoma of the neck both before and after operation. The experience gained from treatment without operation has convinced me that these tumors will usually disappear under heavy Roentgen treatment, and that the results ure more permanent, if the treatment is given first without operation. In nearly every case the mass can be made to disuppear, if the treatment is begun before the glandular involvement is too extensive. After the growth has entirely disappeared, a second series of radiations should be begun as soon as the skin reaction has disappeared. It may be necessary to give a third or even a fourth series of treatments. I have patients apparently well for over four years, the dingnosis having been made microseopically.

My most successful results in sarcoma have been confined chiefly to the lymph nodes. The cancer cases in which Rocntgen treatment has been of the greatest service were those of involvement of the breast, cervical lymph nodes, and other external parts when internal metastasis had not taken place. Roentgen therapy should be applied to deeply seated growths, not with the idea of eflecting a cure, but to eheck the progress of the growth and to make the patient more comfortable. Post-operative treatment should be begun inmediately after the operation. The treatment must be given according to the best judgment of the roentgenologist, and not of the physician or surgeon referring the patient for treatment. Some unfavorable cases can be made fuvorable for operation by anteoperative treatment, and hopeless cases may be treated palliatively with great relief to the patient.

\section{J)ISCUSRION}

Dr. Geonale E. P'rayler, Philadelphia: I saw a case of lymphosurcoma involving the side of the neck which was considered hopeless from every point of view. I treated the patient with the Roentgen ray in the hope that $I$ could give some relief. Within three months the tumor had undergone cystic degenoration. I referred the patient to a surgeon, who opened the cyst and drained it of a large amount of yellowish, pus-like fluid. It was assumed that my diagnosis was wrong, that the case was one of tuberculosis. Pathologic and clinical examination, including the inoculation of guinea-pigs, failed to substantiate that assumption. In about six weeks recurrence was noted and the patient finully died of sareoma. I merely cite the case to show what the Roentgen ray can do in these cases.

1 have had cases of carcinoma in which the course was similar to that cited in the case of sarema. I agree with J). Joggs that the first treatment we lave for these cases in Roentgen therapy. We must give as large a dose as possible, without producing a burn, and persist in the treatment for a long period of time. There are a large number of cases on record in which an apparent cure was obtained by Roentgen treatment, so that a cure under such conditions is by no weans to be regarded as an aecident.
Mr. H. W. Dachtekr, Toledo: A few years ago I refused to treat any case with the Roentgen ray when $I$ was con. vinced that it was perfectly useless. I find now, however, that some patients treated two years ago are apparently well, patients whom $I$ would not huve given any treatment at all had 1 sem them three year's ago. Some surgeons now refer every ease of malignant growth for Roentgen treatment immediately aiter the operation.

Dr. P. M. Hicker, Jetroit: The results obtained by me in several cases of malignant growth have eonvined me that the combined treatment of surgery and Roentgen irradiation.is the proper one, and that it shonld be carried out whenever possi. ble. We can now hold out more hope to the patient than was possible a few years ago.

\section{(To le continued)}

\section{AMERICAN ASSOCIATION OF OBSTETRICIANS AND GYNECOLOGISTS}

Twenty-Fifth Annual Mecting Jeld at Toledo, ohio, Scpt. 17-19, 1912

The President, Dr. X. O. Wendere, Pittsburgh, Pa., in the Chair

\section{Cesarean Section in Double Uterus and Double Vagina}

Dr. N. Srone Scotr, Cleveland, reported the ense of Mrs. A., aged 32 years, primipara, who had always had a moderate Jysmenorrhea, was never very regular, never ahead of time, usually late a week or more; the menstrual period was preceded by a week of pain. She had no idea that there was an abnormality of development such. as was discovered by lier physician at the time of the confinement. After labor lasting three days, the attending physician discovered a sep. tum in the vagina, with a cervix on ench side of the septum, the pregnancy being on the left side. No progress was made in labor. The os was found undilated, although it ensily admitted the finger. The head was high, but firmly impacted in the pelvis. The pelvic manurements were those of an equilibrio justo minor with a conjugata vera of about $9 \mathrm{~cm}$.

A high cesarean section was now carried out. After the placenta and membranes lad been removed, examination proved that the nterus was double, with a rupture of the septum between the two cavities. 'This rupture occurred at the thimnest place, in the middle of the septum, but even here it was a quarter of an inch thick. Through this rupture the false deciclua were removed from the right uterine cavity, the fetus occupying the eavity on the left. The tubes were normally implanted, one at eitlier side of the fundus. There was no eleft in the uterus itself, but a raphe running the entire length of the uterus was plainly seen at the surface.

l'rior to the patient's lenving the hospital, carcful examination was made to ascertain postoperative conditions. The cervix on the right side presented the features of an unim. pregnated cervix; the one on the left corresponding to an ordinary cervix two weeks after delivery; it was considerably. larger than the cervix on the right side, somewhat dilated, and in it was $n$ very small lateral tear. 'The left vagina was possibly a trifle larger than the right, though not much. Both cervices lny comparatively close to the medían partition. On the fourteenth day following the laparotomy, mother and child went home in the best of condition.

\section{Acute Dilatation of the Stomach}

1)R. Cirances Eiwami Zilomer, Pittsburgh, Pa.: I report a case of acute dilatation of the stomach following cesarenn section. Postural treatment and hypodermic medication appeared useless in the ease. The supply of fluid was kept up by rectal and subeutaneous infusion of salt solution. Gastric lavage was the only treatment that eaused any amelio. ration in the symptoms so far as we were able to judge. If there is one thing to be leurned in the treatment of this condi. tion from my case, it is that gnstric lavage in acute dilata. tion of the stomach should be repeated at intervals of not less than two hours. My own feeling is that gustrostomy, with continuous jrrigation of the stomach, ought to be the ideal treatment, and should be given a trial in cases which do not respond to two-hour lavage. 
DISCESSION

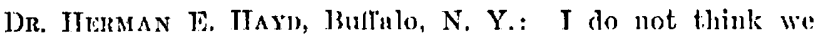
(all put the case rejorted by Br. Davis in the eategory of acute gastrie diatation. Cinfortmately he dill not have a post-mortem exumination. It is possible that this womm lisd it dilated stomach previous to here pregnaney, and that this dilatation was in a measure hatstened by he ndraneing or growing uterus, and just as soon an he empticel the uterns of its contents, the patient hut an acute dilutation of the stomach from the laige nmounts of ether and air that were tiken in. It is unfortmate that we nre compelled to nesept the services of untraned numsthelist.s. One of the most important duties the physicion is culled on to perform is the administration of the anesthetie in an operative ense. We are going to get into trouble before long if we dolegnte this to a nurse. The laws of New York stnte preseribe that no one but a regular mediual graduate may give an nuesthetic.

Dr. Praners Reren, St. Jouis: I think that dilatation of the stomach in these eases is due in many instuneses to the toxic elements of the anesthetic that has been ndministered during a loug period. 'llhere are other toxic elements which will bring about the same condition.

Dr. Syciester d. Goonman, Columbis, reported a ense in which the skull of the fetus hind been erushed by the attending physieian some hours before he saw the womin. The utcrus was full of small filsoids. He advised hysterectomy, which was refised on the gromel that the child was aleat. This woman wats ngain jorghand and he expected to do a second cesarean section the following month.

Jr. Whilan 11. Homston, Clevoland: Cesarean section in an uncontaminated ease is so far safer and surer in its results than the high forceps opreration, that I believe the time is coming when the high foreeps operntion will not be resorted to by the areneral practitioner, but only by the thorcinglily trained man in olstretries.

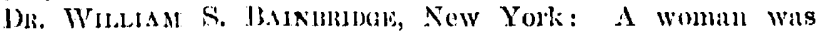
brought to me from J brilgeport, Comm., abont four years ago, with a history of having had six pregnancies, with attemptes at delivery each time, most of them instrumental, with death of the child in ench case. She had a justo minor pelvis and ame to me for repair. The entire pelvie floor was torn away nud the bladder opened. There was a vesicovagintil fistula n4 well as a rectovaginal fistula. I repaired these injuries, and told her she must not become pregnunt ngan, allhough sho was very dexirous of having a living elidk. She came batck to me a your following or a little later pregnint. I told her wo should have to do a cesurenn section, expluined to her what was to be done, and two years ago a eliild was delivered by cesurean section.

DR. A. S. llotaldina, Syrueuse, N. Y.: Two years ago l cid a cestrean section for aclumpsia on a wirl aped 17. She was seven and a half montlis pregnant, with unlilated, ymol)literated cervix. About a month ago she came into the loospital as a private patient, having been brought there by hex physicinn, who thought she wus in labor. I saw her at 9 vedock in the morning. She died shortly after 1 o'elock from hemorrhnge. Autopsy the next morning disclosed rupture of the uterus. The organs were all transposed. The rupture whs directly through the old sear.

Dr. Huoo O. PANTzen, Indianapolis: Bon ring on the multiple etiology of gastric dilatation, I wish to report a ense that ireently came under my olsservation in support of the suppo:ition of 1)r. Javis that in his case neute pressure "pplied to the stomuch muy have been a factor in producing gustric dilatation. The patient, put on a snugly litting corset to attend an automobile race, and was bronghit away from there in convulsions. Fxamination disclosed that she had gastric dilatation which was brought on by constricting her abdomen tou tightly by menns of this corset.

\section{Mechanism and Treatment of Placenta Prævia}

Dr. HENRY SCHwalz, St. Jonis: I. No form of placenta provia, as sueh, ever oflers a justifiable indicution for cesurean vetion. 2. Version after Bruxton-llicks in the preseneo of a viuble child deliberately sacrifiees the life of that child, and lus no place in modern olstetries. 3. 'The cervical and vaginal tampon and the interuterine use of rubber burs are safe and eflicient mouns for controlling hemorrliyge and for securing suflicient dilutation for delivery throngh the matural passinges.

\section{DISCUSSION}

Dr. Je. Guspave Zinke, Cinciunati: It is just as wrong to saly thit eesarean sciction is never indiented in placenta previa as it would be to sny that the only operation for placenta pravia is ecsarean section. When I rend a paper on placenta

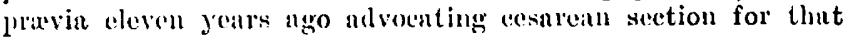
condition, 1 did not find $n$ single sujporter. I was not the first to recommend it for plucent: previl. That eredit belongs to Lawson Tait. I porformed my first cesarean section for placenta pravia about two montls ago. $\Delta$ case of placenta previa centrulis in a normal uterus, in which tho placenta has been formed in the normul way, in which the placental tisstes do not penctrite the uterine musculature and in which the thickness of the uterine wall is uniform throughout, even at the platental site, will nemit of dilatation, in many instances, withont serious hemorrlanges from the hands of a skilful obstetrieian. The situation is entirely different whon we lanve a discalsed musenlature mul a normal implantation of the placentat into the muscle of the nterus. Then there is not the separntion that there is in the other

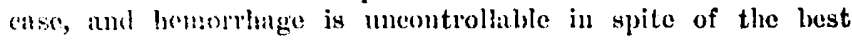
manus of hambling the cose, whether the position be vertex, brech, transverse or what not. Then in alses of rigid os, vien these are hyperplasia nud possibly incipient malignancy Which is not recognized at the time, dilatation does not tako place until the putiont contimses to bleed, and the moment the obstetricinn introdnees his laned for the purpose of dilntation, the patient is likely to be bronght to the verge of death before the child comes out of the uterus. 'These are the enses for which I lave recommended cesarean sertion.

J). Mules li. l'oniter, Fort W'nyue, Ind.: If a woman is in grood health and is known to be the possessor of a viable child at term, with a pliscenta previa centralis, she can be given a better clunce for her own life and that of her child by a cesarean section at the hands of a good man than she ain by any so-called obstetrie procedure at the hands of the best obstetricion ever ereited.

1)k. Jonn Nunv. Bnis, J)etroit: I would take exception to the remurk mide by Dr. Sithwil'z that cesarean section ia not indicater in any form of placenta pravia. My remarks were directed entirely to placenta privia centralis.

Dr. Magnus A. Tate, Cincinuati: In a case of malignney of il fibroid tumor complicating pregnney, I would make a cesarenn section for the malignant condition or for the filoroid tumor, and not for a case simply of placenta previa centrnlis. One of the erying needs at present is for more trinined obstetricians and fewer skilled surgeons.

Dr. Cirannina W. Bahibly, Chicngo: I belicve cesarean section for placenta pravia is suuch overdone in the hands of genemal surgically trinined men. 1 believe, further, that if more of these cases fell into the hunds of truined obstetriciuns, more would be trented through the natural route and fewer cesarean sections would be done.

1)R. Chames L. Bonleimid, Cincinuati: There is no brunch of medicine more neyglected in the medien sthools of to-day than obstetrics, and if there were more traned obstetricians crsitrenn section wonld not be performed as frequently as it is. Tlhere are certain cases, however, in which a skillod surgeon is better than a skilled obstetrician.

\section{Rapid Dilatation and Accouchement Forcé}

Dir. Henry S. Lo'T, Winston-Salem, N. C.: Delivery should be made in all cases of puerperal convulsions, if the patient is at all near full term, on the appenrance of even initial labor pains. With strict ascpsis and forcible, rapid dilatation, preferably manual, the applieation of forceps and clelivery by the natural outlet a'e sufest and will give the best results. belivery should be ellected uncler ether, and with care und doliberation. In the two eases of tear of the sphincter which I report in my paper, I firmly believe thant grenter deliberation in delivery would have lessened the extent of tho injury. 


\section{Puerperal Thrombophlebitis}

Dir. Parmer Finoley, Omalia: Jigation of the pelvic veins in this condition is correct in theory, but is jet in the experimental stage. After reporting four eases, I sulmmit the following propositions for considerntion: 1. 'Trendelenburg's opration is correct in theory, but is yet in the experimental stage. 2. It is contrary to my practice and to modern teaching to open the abdomen in the eourse of pueperal infection unless for drainage in genernl peritonitis, and 1 therefore view Trendelenburg's suggestion with mingivings. 3. We are us yet unable to demonstrate clinically the extent to which the infection has traveled, and hence it follows that an exploratory incision must be the final resort in determining the extent of the infection, though even this nany fuil to give the desires information. 4. The pelvic veins, inctuding the iliaces, may not be thrombosed, yet the infection may attack the veins higher in the aldomen and beyoul eontrol, and exen beyour inspection through an exploratory incision. finthermo:e, lateterial anholi may lodge in the lungs and olsewhere without the formation of thrombosed veins, 5, The thrombosed veins may be secmed and the infection later travel by other avemuses and leat to a fatal issue. f. It is not nlways posibible to demonstrate tike presence of infected emboli which, when found, are viewed ns contan-indications to operative interferenes. 7. I believe that the Trendelenburg operation will find a limited fiekd of nsefulness in olstetric surgery, but that the procedure is worthy of an extended trial.

1). K. Isadome Siskes, l'ittshurgh, Pa., rend a paper in which he reviewed the biterature on thrombophlebitis.

\section{IISclission}

Dir. R. R. Huegrs, Pittsbargh, la.: I believe that recovery oecurs without operation or under palliative treatment in many cases of thrombophlelitis; but my experience shows six cases of the severe form of thrombophlebitis in the last twenty years, with five deaths, with pallintive treatment. I resolved two years ago that in my next case of septic thrombophlebitis I would explore the abdomen and see what the matier was. I did this, and the patient recovered. Since that time I have had three other cases, a totul of four, with three recoveries. 'T'le abdomen should be opened in the milline, which will give a good view of the veins in the pelvis and abdomen. In my experience the operation does these patienty no harm. They stand it very well. Even when there is un necompanying lymphangitis, I do not see any oljection to operating, especially when the condition has extended along the ovarian veins under the retroperitonenl spnce, $a$ position or place in the body which is most dangerous if the condition is allowed to progress. If the veins are tied from within, it is easy to make an extramedian incision, push the peritoneum forward and drain behind the veins, or exeise the ovarian veins down deep in the polvis, and the operntor will not only have lignted the source of infection, but will lave drained the infected spaces, and the pationt is mile: more likely to recover.

\section{Ectopic Gastation.}

Di:. Samule. W. Bariblen, New York: It is dificult to make a positive diagnosis in mnny casen before the stinge of lomintocele, in some eases unlese the lematocele is organizel. Vaginal incision is of value in making the diagnosis, and "blite shinmer" in the vesivo-uterine fold is important.

The specinem shows un exeedingly sinnl! ovum not su?tidently large to fi!l the normally murow Jumen of the istlunian portion of the tube. At this point the tulse whows som. anomalous foutures. A museuta! spur formution is prosent, causing a diverticulum to form with-its blind end buried in the mesosalpinx, and on the mexial aspeet of the point of nidation. The ovum rests on und is imbelded in a musenlan cminenee to the clistul side of the nmscular spur, and it mowhere in connection with the diverticulum on the proxinal risle. It projects into the lumen of the tube lut is coverel by tobal cpithelium. This covering is complete in the hatf nearest the utertes, bat only partially in the lanlf nearest the fimlria, where it may be assumed to sugesest a berinai.ly iatracapsular rupture, and a very carly intratubal rupture.
The embryo as such is not present. It is represented by several large masses and streaks of trophoderm which lie near the trophoblast, and contains fresh blood in contrast to the rest of the congrilum. There is as yet no true chorion formation. Jenkocytes are present underneath the base of the ovum between the loose muscle fiber's, und nowhere else in the serost, musculature or mucosa of the tube. In view of the totul absence of evildence of salpingitis this leukocyte infiltration can be assmmed to indicate a secondary local reaction and not a primary inflammation.

\section{discission}

Dr. J. IlENhy Canstisis, Detroit, repoited a case of pregnancy which sinulated extra-nterine fetation or pus-tube.

\section{Injuries of the Pclvic Floor Resulting From Labor}

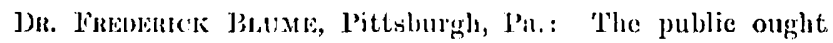
to be informed that injuries of the pelvic lloor are matvoidable in the vatst majority of eases, and that their repair is the end-act of labor. Careful examination and immediate sepair shoukl be the rule in ordinary cisces. If the tear extends into the bowel or through the sphincter, the operntion may lie done on the day following labor, with better light, assiatance, ete. It is strange that even at the present time some olstetricians do not deem it necessary to repair the laceration, but leare the restoration of the pelvie floor to Nature.

\section{The Complete Absence of Milk in the Primipara}

Dr. Frances livinil, Nit. Lonis: The causes that may brin's abont in the lealthy woman a primitive analactia in its extreme degree can be found in a very youthful motherhood, when normally a deficiont development in the secreting eells may be expected. It can be found in the motherhood of advaned age, in which normal atrophic conditions of the ghand have eaused extensive cell destruction. A tendency to futness sometimes completely inlibits the functional activity of the gland. Furthermore, a tendency toward the masculine may seriously affect milk secretion and in rare instances bo the canse of noulactia. J'hysical inlluences, such as emotions of sudden onset, fright, shock, ete., are prone to bring on by their depressing reflex action on the sympathetic nervons system injurions inluences that maty inhibit eell netivity in the organ. In my paper I report three cases of agalactin in three primiparas. In these the cause must be attributed to psychise influenees inamuch as there is no other discoverable factor to which the condition conld be nssigned. It cannot be disputel that the nervous system exerts some influence on milk seeretion. It remuins to be demonstrated whother or not such nu influence is direct or indirect. $\Lambda_{*}$ the method of control for the action of hormones is also lurongh the symputhetie: ganglia, the slock which these primiparas suffered during their severe labor must be looked on as a potent factor in (alusing the agalactia.

\section{Moral and Ithical Aspects of Feticide}

Dr. J. A. Wrsss, l'ittshurnhl, l'a.: $\Lambda$ cureful consideration of the moral anpect of foticide briugs prominently to our attention several facts. 1. The latre number of abortions ferformed is becoming a serious menuce to the health and welfare of our people. 2. Such termination of luman life is a most serious matt'r and every possible safeguard shoul! le taken to restrict it. 3. 'Tluere seems to be a gradually inereasing tendency on the part of the lnity as well as the mofession to tako alvantage of the law and teading which primits and sunctions the induction of ubortion. 4. In most medieal colloges a wtudent has not positive tenching on the moral aspects of alsortion, and he is alfowed to work out his. own idens with regard to its ethicul nspects. 5. There is a gradual loss of reepect for religions teachings which have "lways condemmed the taking of the life of an unborn and mulnptized child as a sin and nurder. 6. Many, if not all the members of this Association, are teachers and leaders in olstetries and gynecology in their respective communities, ani the responsibility of this tenching rests with us. I plead for $n$ more linmane view and considerntion of the rights of the inno:ent unborn child.

\footnotetext{
('2o be cintlutucl)
} 